\title{
大気污染物質の濃度コンターと腐食速度一豊栄市
}

\author{
加藤皓一, $*$ 伊藤保子 \\ 新潟大学 工学部 \\ （テ950-21 新潟市五十嵐 2 の町8050） \\ (*現住所 新潟県衛生公害研究所 $\overline{\mathbf{T}} 950-21$ 新潟市曾和314-1) \\ [平成 4 年 7 月 13 日受理］
}

\section{Contours of Air Pollutant Concentrations and Corrosion Rates of Low Carbon Steel-Toyosaka City}

\author{
Koichi KATOH and ${ }^{*}$ Yasuko ITOH \\ Department of Material and Chemical Engineering, \\ Faculty of Engineering, Niigata University \\ (8050 Ikarashi 2-no-cho, Niigata 950-21) \\ ( ${ }^{*}$ Present address: Niigata Prefectural Research Laboratory \\ for Health and Environment, 314-1 Sowa, Niigata 950-21) \\ [Received July, 13, 1992]
}

\begin{abstract}
Summary
Each of local self-governing bodies has accumulated data of air pollutants. We have tried to make the concentration contours for the pollutants in Nigata city and Kubiki village using the data.

In this paper, we report the contours of chloride ion, sulfate ion, sulfur oxides and nitrogen oxides as air pollutants in Toyosaka city. To express the contours, the equation of smoke diffusion was utilized. The concentrations of nitrogen oxides and sulfur oxides were almost constant all the year round, while those of cloride and sulfate ions decreased in summer season. Probably, the difference depend on the location of the city, since the city is located near Niigata city and Niigata East Harbor (Industrial area).

The specimens of low carbon steel were spread out in the city and the contours of corrosion rates were also drawn. The expected values of corrosion rates were calculated by a multiple regression analysis with chloride and sulfate ions. The values agreed well with the observed values in winter season.
\end{abstract}

Key words: Contour, corrosion rate, low carbon steel, air pollutants

\section{1. 緒言}

各自治体等では工場地帯の污染監視等で大量のデー夕 を蓄積している。このデータの利用の一つとして, 大気 污染物質濃度コンターの作製をすることができる。大気 污染物質コンターを作製することによって，そのデータ を収集した地域の季節的特徴, 地理的特徴が表わされる ために, どの季節, どの地域にはどのような大気污染物
質がどのような広がりであるか図的に把握することがで

き，市の用途別区分などの参考になると思われる。

研究室独自のデー夕を昭和 53 年 3 月から昭和 55 年 5 月 までの期間で測定し使用した。豊栄市内15の測定地点を 定め, 塩化物イオン及び硫酸イオン等はガーゼ法, 硫黄 酸化物と窒素酸化物はアルカリろ紙法で集めたほか, 同 一地点に低炭素鋼板を吊し大気腐食による腐食速度を測 定した。新潟市及び頝城村の測定については既に報告し 
てある2)。

\section{2. 実験}

\section{1 調查地点の概要}

豊栄市は新潟市に隣接し, 面積約 $77 \mathrm{~m}^{2}$, 人口約 46,000 人で主として農産物は米, 野菜, 豚及び果実を生 産し，産業としては紙加工製品，金属製品，空業・土石, 電気機械及び木材を生産している。北部に新潟東港と工 業団地があるため, 市内への潮風及び大気污染物質の影 響をみるための調査を行なった。

\section{2 腐食速度の測定}

低炭素鋼板の試験片 $(2.5 \mathrm{~cm} \times 11 \mathrm{~cm} \times 0.6 \mathrm{~mm})$ を豊栄 市内に設置した。設置地点は 15 か所, 地上 $20 \mathrm{~m}$, 地点間 の距離はおよそ1〜1.5km とした。

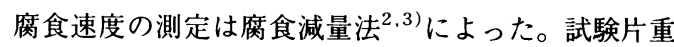
量はあらかじめ重量を測定してから測定地点に吊し，1 か月後に収集した。生じた腐食生成物のみを取る方法は 次の順に作業した。1) ナイフで削って大部分のサビ(腐 食生成物）を除去する。2 ) 剛毛ブラシで付着している サビを落とす。 3 ） 3 \% 硫酸水溶液に有機インヒビ夕ー を液で残りのサビをとる。4）アセトンで洗う。この方 法をとってから乾燥して重量を測った。腐食速度 $(\mathrm{mm})$ は（1）式により算出した。

$$
\text { 腐食速度 }=(10 \times \mathrm{A}) /(\rho \times \mathrm{S})
$$

ここで, A は腐食隇量 $\left.{ }^{3}\right)(\mathrm{g}), \mathrm{S}\left(\mathrm{cm}^{2}\right)$ は試験片の表面 積そして $\rho$ は比重 $\left(\mathrm{g} \cdot \mathrm{cm}^{-3}\right)$ である。

\section{3 大気污染物質の試料採取}

塩化物イオン，硫酸イオンはガーゼ法によった。これ は， $10 \mathrm{~cm} \times 10 \mathrm{~cm}$ のプラスチックス枠にガーゼを張った もので, 1 か月暴露後適当に浸出し, 塩化物イオンはク ロム酸銀法 ${ }^{3.5,6)}$, 硫酸イオンは塩化バリウムーゼラチ ン比濁法 ${ }^{3.7)}$ によった。硫黄酸化物及び窒素酸化物はア ルカリロ紙法で採取したが，定量分析はそれぞれクロラ ニル酸バリウム法 ${ }^{3,8)}$ 及びN-（1-ナフチル）エチレ ンジアミン塩酸塩法 ${ }^{3,9}$ によった。

\section{4 データの前処理}

1 年間のデータは四季にわけた。つまり，3月から 5 月を春， 6 月から 8 月を夏， 9 月から11月を秋及び12月 から翌年の 2 月までを冬として, デー夕を季節ごと平均 値を求めた。地域割は海岸からの距離で分けた。

\section{5 コンターの計算}

コンターの計算には煙の拡散式を利用した。

$$
\mathrm{C}=\mathrm{C}_{0} \exp \left(-\mathrm{y}^{2} / 2 \quad \sigma \mathrm{y}^{2}\right)
$$

Cはある地点でのある污染物質の濃度, $\mathrm{C}_{0}$ は $\mathrm{C}$ 付近での 濃度の高い地点, $\mathrm{y}$ は $\mathrm{C}-\mathrm{C}_{0}$ 間の距離, そして $\sigma \mathrm{y}$ は標 準偏差である ${ }^{1,2)}$ 。実測にあうようにこれを式（3）の ように変形した。

$$
\mathrm{B}=\mathrm{A} \exp \left(-\mathrm{dx^{2 }}\right)
$$

$\mathrm{B}$ は C (ppm)，A は $\mathrm{C}_{0}(\mathrm{ppm})$ に相当する。 $\mathrm{x}$ は地図上 の距離で $\mathrm{cm}$ 又は $\mathrm{mm}$ で表わされる。d は定数で $1 / 2 \sigma \mathrm{y}^{2}$ に相当する。作図の方法を Fig. 1に，コンターを書くた めの区分け値を Table 1に示す。当然この区分け値を大 きく取るか，小さく取るかによってコンターの線があら くなったり，密になったりする。この報告では濃度の大

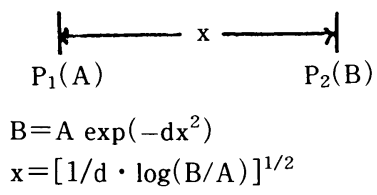

Where $\mathrm{A}$ and $\mathrm{B}$ are concentrations (ppm) and $\mathrm{x}$ $(\mathrm{mm}$ or $\mathrm{cm})$ is the distance between site $\mathrm{A}$ and $\mathrm{B}$ on a map.

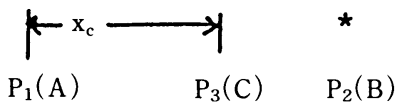

1. Case of one highest point in an area

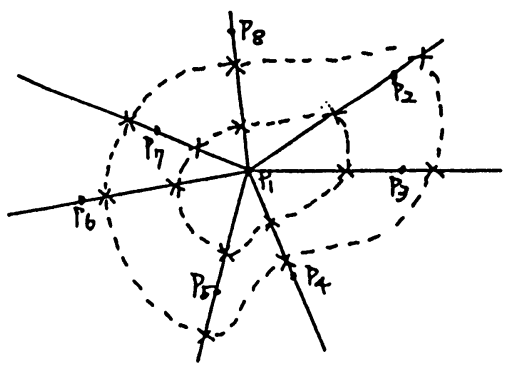

2. Case of two highest points in an area

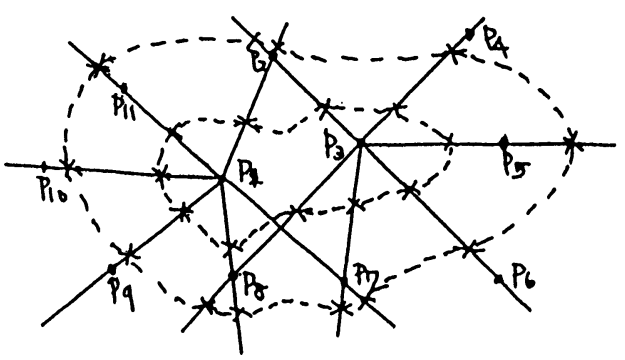

Fig. 1. Calculation and drawing 
Table 1. Classification of the pollutants and corrosion rate

$\begin{array}{llcccccr}\text { Substance } & \text { Unit } & \text { Rank I } & \text { II } & \text { III } & \text { IV } & \text { V } & \text { VI } \\ \text { Chloride } & \text { C } & \sim 10 & 10 \sim 20 & 20 \sim 35 & 35 \sim 50 & 50 \sim 70 & 70 \sim \\ \text { Sulfate } & " & \sim 10 & 10 \sim 20 & 20 \sim 30 & 30 \sim 35 & 35 \sim 40 & 40 \sim \\ \text { SOx } & C^{*} 1000 & \sim .05 & .06 \sim .08 & .09 \sim 0.10 & .11 \sim .15 & .16 \sim .28 & .29 \sim \\ \text { NOx } & \text { C } & \sim .06 & .07 \sim .12 & .13 \sim .20 & .21 \sim .35 & .36 \sim .55 & .56 \sim \\ \text { Corrosion Rate } & \sim 35 & 35 \sim 45 & - & 45 \sim 55 & 55 \sim 75 & 75 \sim\end{array}$

Chloride, Sulfate, SOx, NOx, Corrosion rate: '78, June '80, May C : $10^{-6} \mathrm{~g} /$ day $\cdot 100 \mathrm{~cm}^{2}$, Corrosion Rate $: 10^{-4} \mathrm{~mm} / \mathrm{month}$

Table 2. Mean values of the pollutants and corrosion rate for four seasons

\begin{tabular}{llcccc} 
& \multicolumn{1}{c}{ Unit } & Spring & Summer & Autumn & Winter \\
Chloride ion & C & 35.1 & 8.1 & 24.4 & 51.8 \\
Sulfate ion & C & 13.9 & 11.3 & 20.3 & 27.7 \\
Sulphur oxides & C $^{*} 1000$ & 0.20 & 0.14 & 0.17 & 0.19 \\
Nitrogen oxides & C & 0.12 & 0.11 & 0.11 & 0.12 \\
Corrosion rate & & 47.1 & 34.8 & 49.9 & 60.1
\end{tabular}

Chloride, Sulfate, SOx, NOx, Corrosion rate: '78, June '80, May

C : $10^{-6} \mathrm{~g} /$ day $\cdot 100 \mathrm{~cm}^{2}$, Corrosion rate: $10^{-4} \mathrm{~mm} /$ month

小を問わず6つに区分けした。

\section{3. 結果および考察}

\section{1 大気污染物質濃度の季節变化}

\section{1.1 塩化物イオン}

冬が高く，夏が低い分布を示している。この様子を季 節別に各大気污染物質及び腐食速度の平均值を Table 2 に示す。海岸からの距離との間には明確な関係は認めら れなかった。春は人口密度の高い地帯 5 地点付近が $\mathrm{V} ラ$ ンク, 北東部の果実畑のある 1 地点付近が I ランク, $\mathrm{V}$ を示した周辺と南東部の田園地帯と人口密集地の混在し ている12地点付近が $I N$ ラクとなり, その周辺の田園部 は 1 ランク低くなり吕を示した。夏は I と II ランクが全 域を占め, 秋は春を 1 ランク下げた形に似ており, 冬は 冬の腐食度コンターに似ていた。この春の例を Fig. 2に 示す。

\section{1.2 硫酸イオン}

秋と冬が高く, 春と夏が低い分布を示している。春で は 5 地点付近に塩化物イオンのときと同様な形のIIIラン クが示され, 夏は I と II ランクが全域を占めたが, 塩化 物イオンのコンターとは異なった。秋では 5 地点付近と 東南部12地点付近でVランクを示したが, この付近に硫 酸イオンを発生するような所はない。冬でもこの地点に

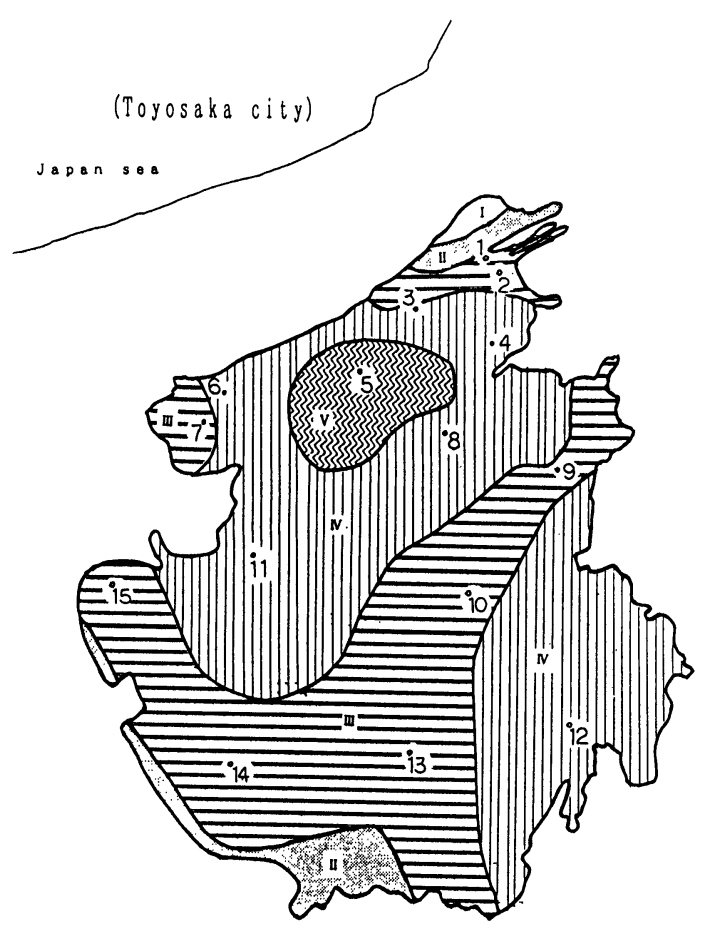

Fig. 2. Contour of chloride ion in Toyosaka (Spring) 
VIランクが示された。今後原因を検討する必要がある。 硫酸イオンの春の例を Fig. 3に示す。

\section{1.3 硫黄䤒化物}

冬が最も高く，夏が最も低い分布を示している。春は 15 地点付近にVIランクが示され，約 $80 \%$ が $N$ ランク以上 であったが，これが夏になるとほほ全面的にII ランクと なった。秋になると10地点付近がIVランクとなり，市の 周辺がII ランクだったが，冬では市街部のやや南側の中

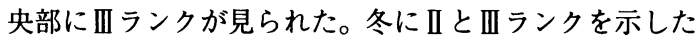
1 地点付近が夏にIIIランクを示したのは奇異であった。 春の例を Fig. 4に示す。

\section{1.4 窒秦酸化物}

春は非常に複雑な形を示した。つまり 9 地点付近がVI ランク， 4 地点付近にVランクがあってその間にIVラン クがあった。南部は I ランクだった。夏では 7 地点付近 にりランクが移ったが，ここにバイパスがある。秋もこ の 7 地点付近がVランクであった。冬ではこの地域が広 がり 6,7 と11地点付近がVランクとなった。春にI ンクを示した南部は四季を通して污染度は低かった。細 かいところを除けば夏秋冬のパターンが似ていた。春の 例を Fig. 5に示す。

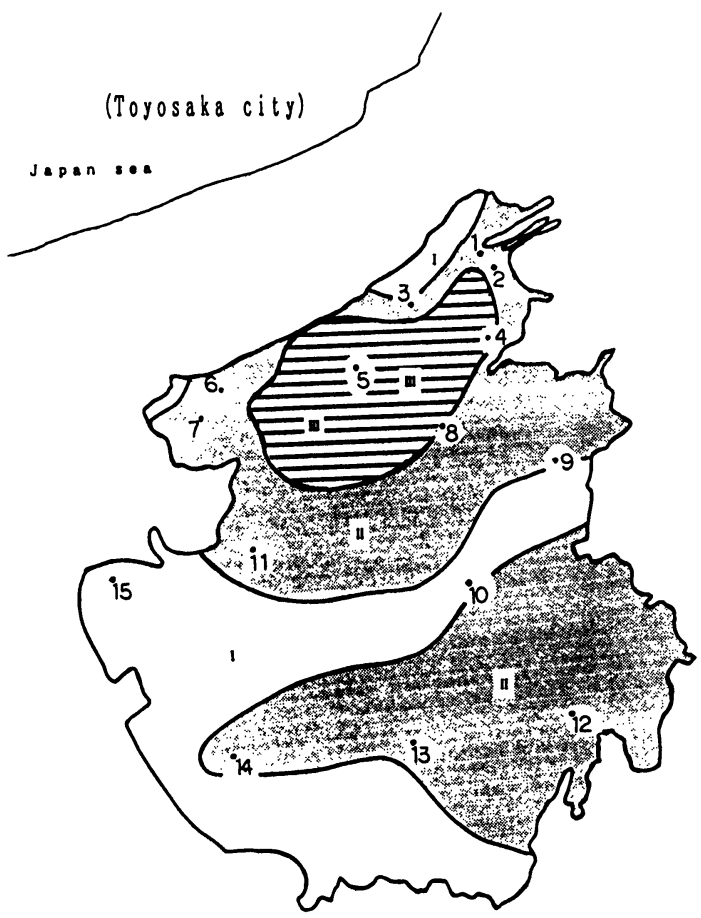

Fig. 3. Contour of sulfate ion in Toyosaka(Spring)

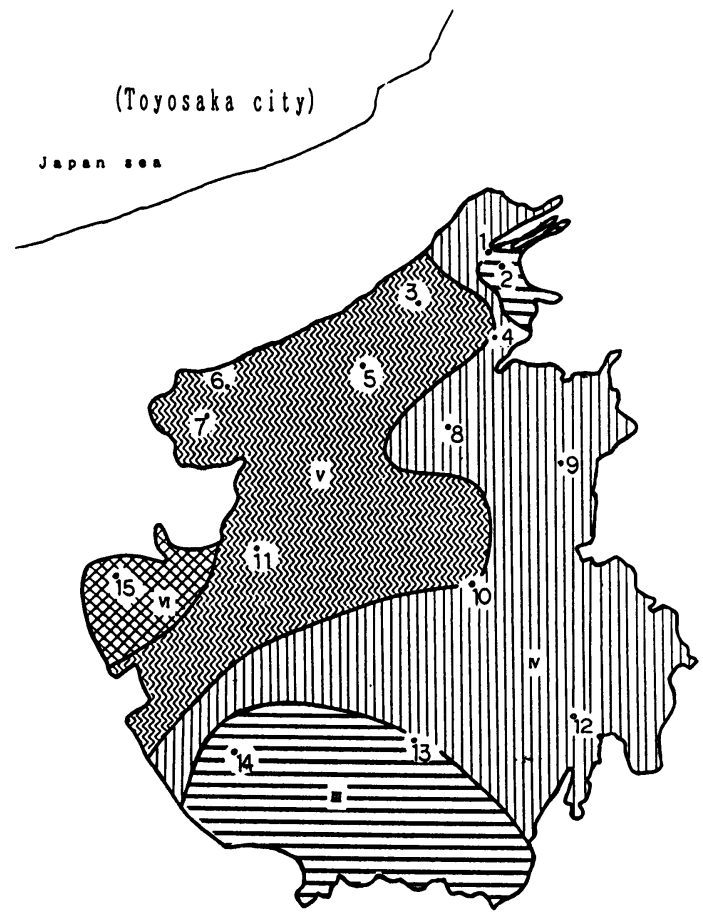

Fig. 4. Contour of sulfhur oxides in Toyosaka (Spring)

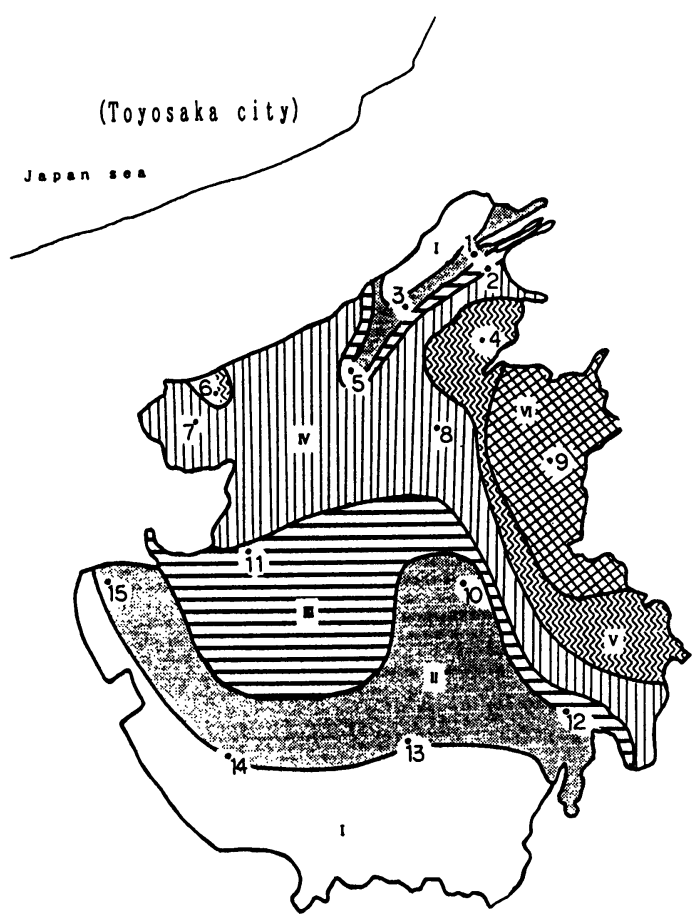

Fig. 5. Contour of nitrogen oxides in Toyosaka (Spring) 


\section{1.5 腐食速度}

冬が最も高く IVランク以上が大部分を占め，夏は I と II ランクが大部分を占めた。春は 5 と 7 地点付近 Vラン クが示された他， 1 地点付近と南部にI ランクが示され た。秋は $2,4,5$ と 6 地点付近にVランクが示され, 市 の中央から南にかけて細長くI ランク地帯が示された。 この付近は田園地帯である。春の例を Fig. 6に示す。

\section{2 席食速度の予测}

先に新潟市における重回㷌分析 ${ }^{4)}$ を行なった。この際, 腐食速度を目的変数, 大気污染物質因子 (塩化物イオン, 硫酸イオン, 硫黄酸化物及び窒素酸化物) と気象因子 (風 速，気温，日照時間，日射量，降雨量及び湿度）を説明 変数として変数減量法 ${ }^{10)}$ を用いて検討した結果, 塩化 物イオンと硫酸イオンのデータから腐食速度を予測でき ることが分かったので，豊栄市についても同様に予測し てみた。重回帰式の寄与率は春で0.8930, 夏で0.1089, 秋は0.6016, 冬は0.8098であった。冬の例を Fig. 7に示 す。春は硫酸イオンが $1 \%$ 有意を示し, 冬は塩化物イオ ンが $5 \%$ 有意を示した。冬は季節風が強く塩化物イオン を海から運ぶが, 春は風が弱いので海から運ばれる硫酸 イオンと陸の硫酸イオンとが重なって相対的に塩化物イ オンの影響が弱まるものと思われる。実測値と予想値の 一致は良好といえる。

\section{要 約}

各自治体等で大量に蓄積している大気污染監視データ を利用する 1 つの方法として大気污染濃度コンターの作 製を試みた。すでに新潟市と頝城村について行なったの で, 豊栄市で試みた。コンターには煙の拡散式を利用し た。大気污染物質として塩化物イオン, 硫酸イオン, 硫 黄酸化物及び窒素酸化物を調査した。全体的にみて, 冬 に高く夏に低い傾向はあったが, 窒素酸化物は年間を通 してほとんど変動なかった。また, 硫黄酸化物は夏と冬 の差が小さいなどの特徴があった。これは, 新潟市と新 潟東港と隣接しているためと思われる。

\section{謝 辞}

この研究を進めるにあたりデータを収集に協力して下 さった豊栄市の職員の皆様に感謝します。

\section{文 献}

1) J. CRANK: Mathematics of diffusion, Oxford Univ. Press, London, 2-5, (1975)

2) Koichi KATOH: Contours of air pollutant concentrations and corrosion rates of low carbon steel, Analy. tical Sciences, 7, Supplement, 1017-1020（1991）

3) 安川三郎, 加藤皓一, 安田守宏, 今泉 洋: 新潟市

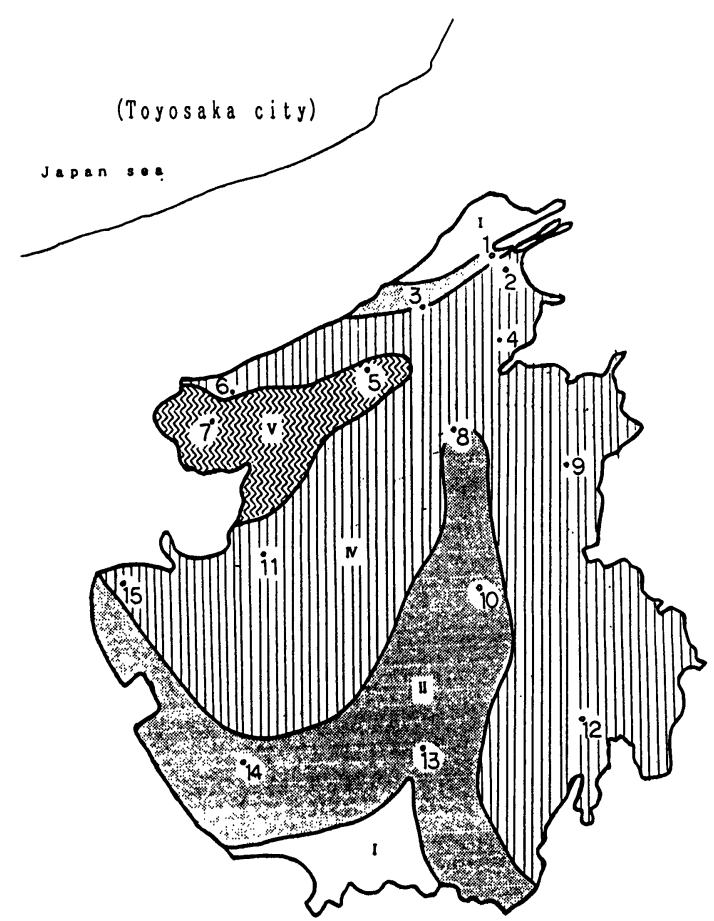

Fig. 6. Contour of corrosion rates in Toyosaka (Spring)

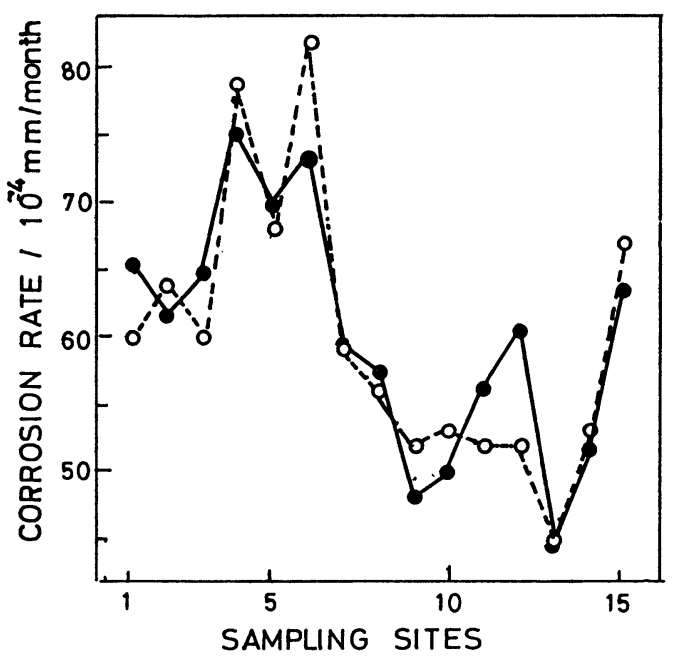

Fig. 7. Expected values of corrosion rates by mutiple regression analysis Expected: Obsetved: $\bigcirc$

における炭素鋼の 1 か月大気暴露による腐食，防食 技術，29，609-614（1980）

4) 安川三郎, 加藤皓一, 安田守宏, 田中 肇：新潟市 における炭素鋼の大気腐食に関する重回㷌分析, 防 
食技術，32，195-201（1983）

5) Koichi KATOH and Shinichi TAKAHASHI: Interferences of Anions or Cations in Spectrophotometric Determination of Chloride Ion by Silver Chromate Method for Natural Water, Research Reports of the Faculty of Engineering, Niigata University, No.34, 21-25 (1985)
6) 塩化物イオン：JIS K0101 (1966) 25. 3

7）硫酸イオン：JIS K0101（1966）31. 2

8）硫黄酸化物：JIS K0103 6. 1. 3

9）窒素酸化物：JIS K0104 参考法

10）奥野忠一ほか 5 名：続多变量解析法, 日科技連出版 社 (1976) 